\title{
Communication of political interest groups in Switzerland: Adressees, channels and instruments
}

\author{
Jentges, E ; Brändli, M ; Donges, $\mathrm{P}$; Jarren, $\mathrm{O}$
}

\begin{abstract}
We present a broad overview on the Swiss interest group population and the results of a quantitative online survey on the communication repertoire of 985 interest groups. We then discuss sample construction and the different addressees of interest group communication, the perceived relevance of mass media channels, and which instruments and measures are used to communicate with external and internal environments. We identify four different logics - influence, support, reputation and reciprocity - that influence the communication activities of political intermediaries such as interest groups.
\end{abstract}

DOI: https://doi.org/10.1016/j.scoms.2013.04.004

Posted at the Zurich Open Repository and Archive, University of Zurich

ZORA URL: https://doi.org/10.5167/uzh-78618

Journal Article

Accepted Version

Originally published at:

Jentges, E; Brändli, M; Donges, P; Jarren, O (2013). Communication of political interest groups in Switzerland: Adressees, channels and instruments. Studies in Communication Sciences, 13(1):33-40.

DOI: https://doi.org/10.1016/j.scoms.2013.04.004 
MANUSCRIPT PREPARED FOR SCOMS (revise and resubmit, February 2013)

Jentges, Erik / Brändli, Matthias / Donges, Patrick / Jarren, Otfried

Communication of political interest groups in Switzerland: Adressees, channels and instruments

Abstract (83 words):

We present a broad overview on the Swiss interest group population and the results of a quantitative online survey on the communication repertoire of 985 interest groups. We then discuss sample construction and the different addressees of interest group communication, the perceived relevance of mass media channels, and which instruments and measures are used to communicate with external and internal environments. We identify four different logics - influence, support, reputation and reciprocity - that influence the communication activities of political intermediaries such as interest groups.

The article is based on data from the NCCR Democracy research project Mediatization of political interest groups and is funded by the Swiss National Science Foundation (SNSF).

Keywords: political communication; communication repertoire; interest groups; Switzerland

Dr. phil. Erik Jentges, IPMZ, University of Zurich, Andreasstrasse 15, CH-8050 Zürich, Switzerland

lic. phil. Matthias Brändli, IPMZ, University of Zurich, Andreasstrasse 15, CH-8050 Zürich, Switzerland

Prof. Dr. Patrick Donges, Department of Political and Communication Science, University of Greifswald, Rubenowstrasse 3, 17487 Greifswald, Germany

Prof. Dr. Otfried Jarren, IPMZ, University of Zurich, Andreasstrasse 15, CH-8050 Zürich, Switzerland

Corresponding author:

Dr. Erik Jentges, Andreasstrasse 15, 8050 Zurich; e.jentges@ipmz.uzh.ch 


\section{Introduction}

"Swiss democracy is geared to pressure groups; it is a form of government calculated to bring such groups into existence and give them power. The system could conceivably continue for a time without parties, but without pressure groups it would not work at all" (Katzenstein 1984: 112).

Pressure groups or political interest groups are key actors in Swiss politics. Some assessments of interest groups in Switzerland go as far as to hypothesise a manipulation of the will of the people and the corruption of democratic processes (Baeriswyl 2005). Leaving such normative criticisms aside, it is appropriate to consider them as influential political players that can be as important or more important than parties (Church 2004; Mach 2007; Kriesi \& Trechsel 2008). As actors in an open and functioning intermediary system between the state and the society, they are relevant for modern democracies (Habermas 2006; Armingeon 2007; Jordan \& Maloney 2007; Halpin 2010). However, there are many studies on interest groups and how they perceive the importance of the media's role in their day-to-day activities. There are also numerous studies on intermediary actors and their relationships with mass media (Hackenbroch 1998; Vowe 2007; Donges 2008; Steiner \& Jarren 2009; Koch-Baumgarten 2010; Binderkrantz \& Krøyer 2012; Dür \& Mateo 2013), but there remains a need for a systematic overview of both the population of interest groups in Switzerland as well as their communication strategies and repertoires.

The strength of interest groups in Switzerland has historical origins. Even prior to the development of political parties, firms and small manufacturers organised into national umbrella organisations. The corporatist tradition dates back to at least the 18th century, when guilds of traders and craftsmen (Zünfte) participated in the governance of economic and political affairs in the cities. Trade unions emerged in the second half of the 19th century. At the beginning of the 20th century, almost 150 organisations existed, more or less evenly divided into employer associations and associations representing workers and professionals (Church 2004: 72). Subsequent differentiation of the interest group system has led to an explosion of interest representation in all policy sectors. Sidjanski (1974) outlined the structures of the Swiss interest group landscape and highlighted the importance of groups in the referendum and the initiative. Due to the provisions of direct democracy, they can mobilise members and the citizenry in general to initiate public debates and call for referenda on their particular issues. Pre-parliamentary consultations (Vernehmlassungsverfahren) 
guarantee that marginal interests are heard. The embedding and formalised integration of interest groups into political processes is quite particular, compared to other countries. Policy studies that address the interactions between politicians, journalists and interest representatives - for example Wenzler (2009) - have offered insights into the dynamics of the Swiss energy and cultural policy sectors.

Overall, Swiss national political tradition is based on a unique form of 'democratic corporatism' (Mach 2007: 369; Zeigler 1993). According to Katzenstein (1984), its characteristics are "a centralized and concentrated system of interest associations; a voluntary and informal coordination of the various interests in continuous political negotiations between their associations; political parties and the various branches of public administration; and an ideology favouring social partnership" (summarised in Kriesi \& Trechsel 2008: 99). Another relevant aspect is rooted in the militia system's peculiarity: "some staff members of important BIAs [business interest associations] and employees of major corporations have always held seats in the national Parliament for these parties and major corporations have always relied on their members in the Parliament to represent their interests" (Kriesi \& Trechsel 2008: 114). Building on these aspects, our research seeks to provide a descriptive overview of the landscape of interest groups in Switzerland and to map their communicative activities. Who are their addressees, through which channels do they communicate, and which instruments do they use?

\section{Methodology}

\subsection{Political interest groups}

An analytical definition is important if researchers are confronted with an enormous variety of intermediary organizations, ranging from trade unions, employers' and professional associations to large and small civil society organizations. We have chosen the definition of political interest groups that researchers from the ECPR Standing Group on Interest Groups use. They define political interest groups via their shared characteristics: political interest, organisation, and informality (Beyers, Eising \& Maloney 2008).

Political interest refers to activities related to monitoring and influencing policy processes. Relatively few interest groups regularly and professionally work on political issues; most 
groups are policy amateurs and are not continuously politically active. The aspect of organisation relates to an institutionalised administrative infrastructure, in other words, interest groups differ from both waves of public opinion and non-institutionalised social movements. Informality indicates that interest groups do not stand for elections and refrain from claiming public office.

Concerning the communication of interest groups, political theory distinguishes between an outward orientation to policy-makers and inward orientation to members. Accordingly, groups are assumed to operate with the logic of influence and the logic of membership logic (Streeck 1994), or with the logic of information and the logic of support (Roose 2009). This framework was recently extended to consider the media's role and the importance of a public image for interest groups. Berkhout (2010) argues that a third logic - one of reputation needs consideration when assessing interest groups' outward communication with news media. This is crucial for public interest groups that depend on donations and whose main asset is their public image, but it has some relevance for all interest groups. In addition, we hypothesise that interest groups are not solitary monadic actors but have characteristic interdependencies, both formal (institutionalised) and in informal networks, with other associations in their policy circles and organisational fields. We explore whether this fourth logic of reciprocity becomes visible with which groups aim to share information between organisations in the intermediary network. These four logics are better understood as orientations and attempts to sort out the communicative activities of intermediary organisations with different environments. The well-institutionalised Swiss interest group system and the strong standing of groups in the political process presents us with an ideal background to research these four logics of organisational communication.

\subsection{Sampling}

Empirical research on interest groups is confronted with challenges in sample building (see the contributions in Halpin \& Grant 2012). It is nearly impossible to count the total actor population, since new actors often emerge, older ones merge into larger alliances, and many policy amateurs only become active and therefore visible when their issues are on the political agenda. Following the method suggested by Wonka et al. (2010), we compiled different data sources and sampled entries from public encyclopaedias, public affairs handbooks, online registries, and parliamentary consultations with relevant political associations. A database on the Swiss interest group population was created by drawing on the following sources: The 
2010 online version of the Publicus, a registered handbook of public life published by Schwabe Verlag in Basel, which provided a sample of 1.812 organisations. Data was then added from www.verbaende.ch, a Swiss website that supports the work of interest associations and which contained addresses of approximately 1.300 national organisations that influence Switzerland's political and economic affairs. ${ }^{1}$ A total of 1.152 organisations fulfilled the criteria of our definition of interest groups.

We then added lists by the National Council (Nationalrat) and the Council of States (Ständerat), because both institutions have registries for the access passes issued for the lobby of parliament (Bundeshaus). Each parliamentarian is allowed to hand out two passes to the building; these usually go to secretaries, scientific counsellors, family members, friends and interest group representatives, resulting in a total of 128 interest organisations with admission to the building. Since the Swiss militia system allows to parliamentarians - both in the National Council and in the Council of States - to work in political organisations during their mandate, their affiliations must be made public in the Interessenbindungsregister, the group affiliations registry. Another 294 organisations could be identified. We then added interest groups that were contacted in pre-parliamentary consultations. The Swiss government addresses all potentially affected organisations concerning specific policy proposals and compiles a registry of who has been informed and invited to voice their opinions. All organisations listed for 2010 and 2011 were coded, a total of 1.250 organisations. The European Union lobby registry was scanned for organisations based in Switzerland, assuming that they do not only lobby the EU; 21 organisations were added. Finally, we consulted the database assembled on the EU interest group population (Wonka et al. 2010); it delivered 59 entries for organisations from Switzerland. In total, a dataset of 4.716 organisations was assembled. After deleting duplicates, 2.649 organisations remained.

The registries were then merged. Existing entries were systematically screened, and all organisations that fulfilled our definition of interest groups were coded. At this preparatory stage, a first coding process included the main political activity level, central office location, organisations' internet and email addresses and, where possible, personal email addresses from an organisation's communication department. A manual check of the coding of policy fields was made; missing email addresses were added where they could be obtained from

\footnotetext{
${ }^{1}$ The website is set up by and for interest associations and serves as an information platform. Any association and service provider may enter their contact details. There is little editing of addresses and no information about database maintenance.
} 
websites. In total, 2.475 organisations with identifiable email addresses were contacted with an online questionnaire. An overview is provided in Table 1.

Table 1: Swiss interest group population

\begin{tabular}{ll}
\hline Dataset & $\mathrm{n}$ \\
\hline Publicus & 1.812 \\
\hline Verbaende.ch & 1.152 \\
Registry of guests to the Bundeshaus & 128 \\
Registry of parliamentarians' interest affiliations & 294 \\
Vernehmlassungen 2010 and 2011 (invitees to consultations on Referenda) & 1.250 \\
EU registry of interest representatives & 21 \\
EU interest group population & 59 \\
\hline \hline Total groups listed in all 7 sources & 4.716 \\
\hline \hline After deleting duplicates & 2.649 \\
Total groups with email addresses & 2.475 \\
\hline \hline Groups participating in the survey & 985 \\
Response rate & $40 \%$ \\
\hline
\end{tabular}

\subsection{Online survey}

The method of surveying with an online questionnaire is the most cost-efficient way to contact interest groups. The questionnaire dealt with the organisations' positions in the political and media system, with the respondents' perceptions of intensity of political competition as well as the groups' frequency of political activity. We specifically asked for the main addressees of political interest groups' communication. Concerning communication repertoires, we asked which communication instruments are implemented in external communication (i.e. to policy-makers, journalists or the public), in internal communication (to their members and supporters) and in the monitoring of external environments. Concerning the research instrument, it must be noted that a researcher has little control over who actually answers the questionnaire.

The contact letter set the tone for dealing with our request. It was addressed to representatives of the communication department if such positions could be identified, or the top of the organisational hierarchy. It cannot be ruled out that, in some cases, the questionnaire was delegated to other persons. Participating organisations were offered an incentive in form of a brief case-specific analysis of the data. After a follow-up email reminder, a total of 985 organisations completed the questionnaire. The $40 \%$ response rate is satisfactory. While representativeness cannot be deduced for the intermediary system from this sample, a 
crosscheck of the responses showed that regional distributions matched the initial questionnaire mail-out and, in this sense, correspond geographically.

\section{Results}

\subsection{Population}

The Swiss intermediary system is highly institutionalised. If the number of sampled associations is related to the population, the organisation density is 24 associations per 100.000 citizens. This ratio is partially explained by the strong federalism ( 26 cantons) and the necessity to recreate organisational infrastructures in three language areas. This highly diversified intermediary system's ratio is about four times higher than that of Germany, owing in part to several ruptures in German political history, which affected the development and differentiation of its intermediary system and led to a more centralised federalism with a stronger role for national umbrella organisations. This indicator for the intermediary network's relative density shows that the intermediaries between citizens and policy-makers create a dense organisational field.

Concerning geographical distribution (Table 2), the majority of interest groups are found in the German-speaking part of Switzerland, especially in Zurich, the economic centre, and Berne, the national capital. This regional distribution was already described by Sidjanski (1974: 104-105) and has remained virtually unchanged. Of the 985 participating interest groups, $878(89.1 \%)$ are located in the German-speaking part of Switzerland. 91 associations $(9.2 \%)$ are located in the French-speaking part of Switzerland and $16(1.6 \%)$ in the Italianspeaking part. The relatively low numbers of French-speaking and Italian-speaking interest groups should be viewed in the light of a hierarchically stacked and interconnected intermediary network with strong and centralised national umbrella organisations. The numbers should thus not be read or used as an argument that Romand or Ticinese interests are underrepresented - such statements are invalid. Further analyses have shown that the language regions do not account for significant differences in interest groups' communication activities. Comparisons between groups from German-speaking and French-speaking parts of Switzerland also show strong distribution similarities across the various sectors. Data for the Italian-speaking part was dropped due to the small sample size. In order to use the largest possible dataset, the results are based on unified responses to the questionnaire $(n=985)$. 
Concerning distribution across different sectors, the population is characterised by a large share of economic and employment organisations. This sector contains employers' organisations, trade unions and various professional associations. The category 'other' was an open text field and was used by $18.7 \%$ of the respondents to avoid categorisation and to highlight the uniqueness of the respondent's organisation. It shows that many organisations are multipurpose associations that are continuously active in several sectors, or active in different sectors at different times, for example in various campaigns, initiatives or referenda. They consciously refrained from being placed in a specific box, indicating the analytical limits of a rigid categorisation scheme.

Table 2: Overview of interest group population (survey participants)

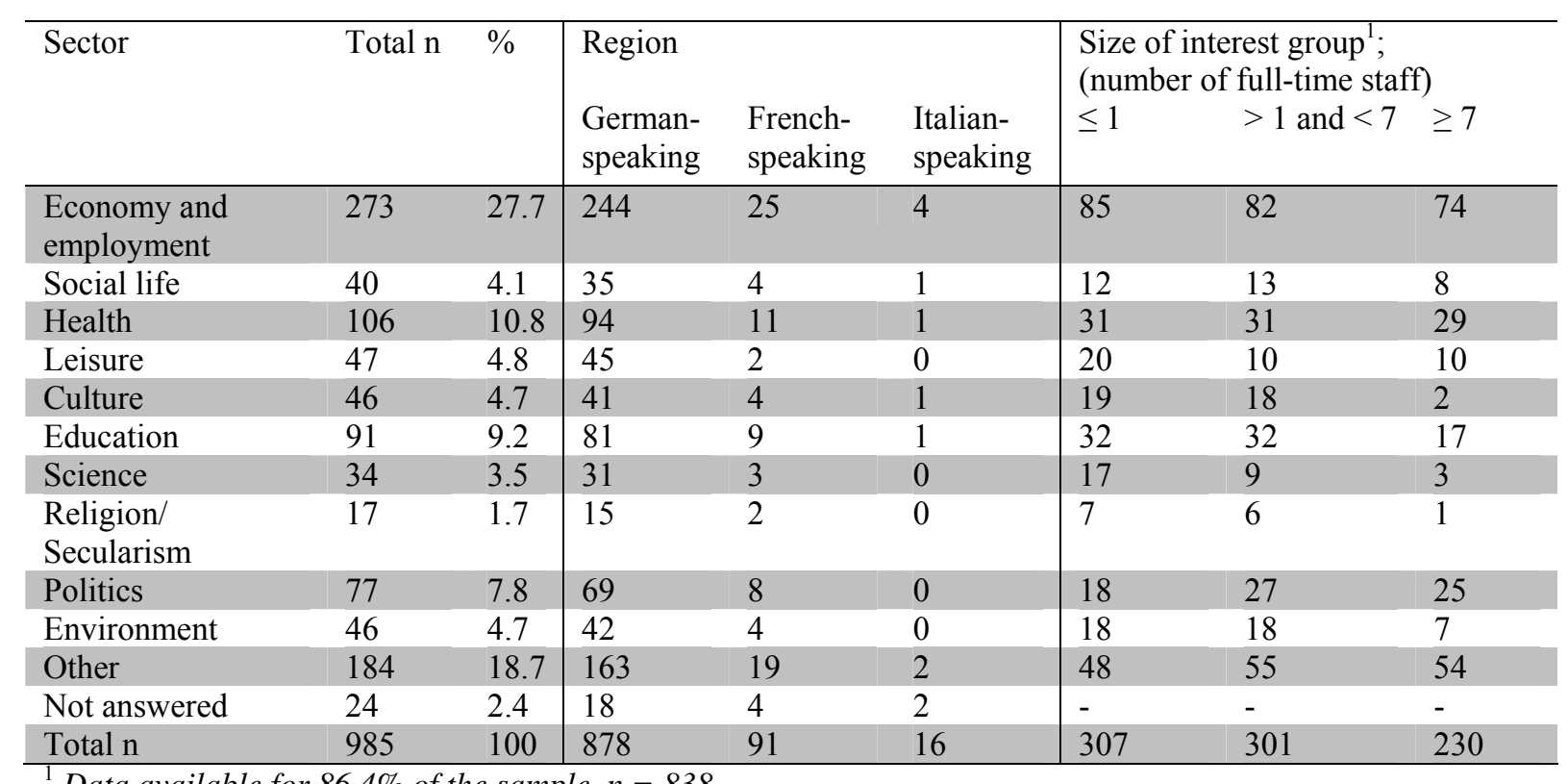

${ }^{1}$ Data available for $86.4 \%$ of the sample, $n=838$.

To show the intermediary system's development over time, the interest groups' founding years were mapped out. Disregarding a handful of early starters, the functional differentiation of the intermediary system, with an exponential growth of interest groups since the second half of the 19th century, becomes visible (Figure 1). Since there is no data available on how many groups discontinued their work or merged into larger organisational arrangements, the data must be treated with caution. Still, the surviving interest group population has become much larger over the past 150 years, with a peak around the 1970s. Since 2000, it seems there has been a slowdown in the number of interests groups set up. One could speak of a 
consolidation within the interest representation system in Switzerland at a high degree of functional differentiation. Only a few collective interests have not find an organisational outlet for representation. In addition, a time lag of five to ten years between an organisation's foundation, its appearance on the political field and its recognition in registries must be taken into account, in other words, there may be continued de facto growth without this being reflected in the data yet.

Figure 1: Founding years of interest groups

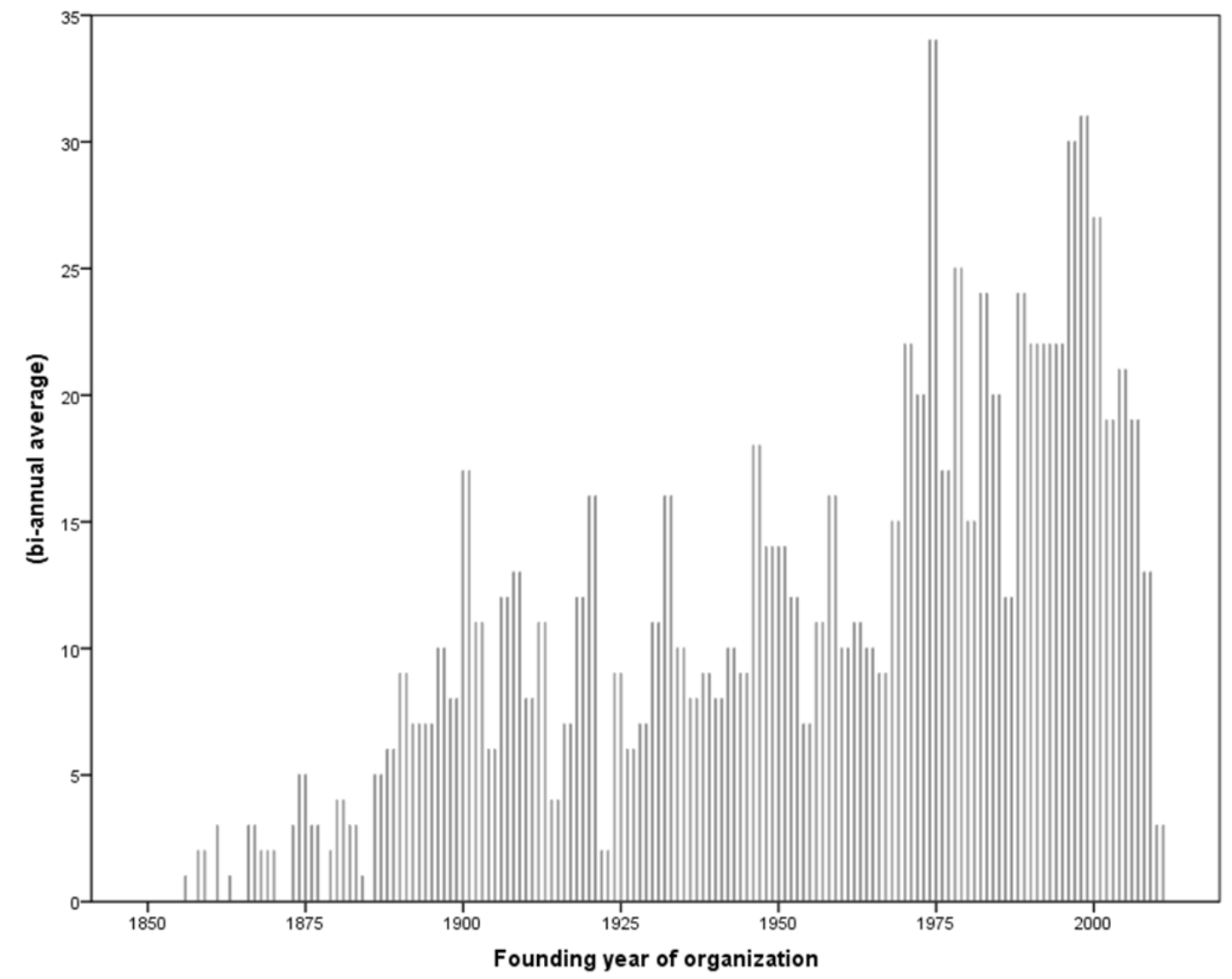

\subsection{The addressees of interest group communication}

The initial research question of how political interest groups perceive the media's importance and role in their day-to-day-activities was approached by asking for general communication routines. To compare the relevance of media as an important environment along with other stakeholders in an organisation's external and internal environment, respondents could choose between eight different groups of addressees. Possible addressees covered government and 
administration, parliamentary factions and political parties, the media, own members, other associations and interest groups, citizens, scientific and academic bodies, and a free text field for other contacts; the latter option was seldom used and was thus discarded for further analysis. Responses showed that four different addressees are given high priority (Table 3 ). These are own members, as the key stakeholders of an organisation's internal environment, and three external environments: government and administration, media, and other associations and interest groups.

The most important addressees are own members (at 73.9\%) and government and administration $(60.2 \%)$. On the one hand, intermediaries try to connect with their supporters both individual and institutional members to whom they are bound via the logic of support and on the other hand, with governments and administrations via the logic of influence. This is followed by media, at $47 \%$. In communication with media and journalists, the logic of reputation seems relevant (Berkhout 2010: 53). Considering that relatively few interest groups continuously prefer outside lobbying (these organisations - such as Amnesty International and Greenpeace - are also publicly known from news coverage), the relatively high number can be read as a fairly pronounced marker for the mass media' relevance as an important institutional environment for political intermediaries.

Other interest groups were seen as extremely or very important addressees by $41.5 \%$ of the respondents and even ranked above parliamentary factions and political parties $(35.6 \%)$. Political interest groups also seem to have fewer direct links to citizens, since only $21 \%$ of the respondents reported that citizens are extremely or very important. Communication with scientific or academic institutions is considered very importance by only $18 \%$ of the interest groups.

Table 3: Importance of addressees for interest groups $(n=985$, in \%)

Question: "Considering individuals or groups of people with whom you routinely communicate on political issues, how important are the following contacts for communication by your organisation?" (5-point scale)

\begin{tabular}{lllllll}
\hline & Mean & $\begin{array}{l}\text { Standard } \\
\text { deviation }\end{array}$ & $\begin{array}{l}\text { Extremely } \\
\text { or very } \\
\text { important }\end{array}$ & Important & $\begin{array}{l}\text { Less } \\
\text { important or } \\
\text { unimportant }\end{array}$ & No answer \\
\hline Own members & 2.72 & .54 & 73.9 & 17.4 & 4.6 & 4.2 \\
Government and administration & 2.49 & .73 & 60.2 & 22.4 & 13.4 & 4.0 \\
Media & 2.33 & .74 & 47.0 & 32.4 & 15.8 & 4.8 \\
\hline
\end{tabular}




\begin{tabular}{lllllll}
\hline Parliamentary factions or parties & 2.01 & .86 & 35.6 & 24.4 & 34.4 & 5.6 \\
$\begin{array}{l}\text { Other associations and interest } \\
\text { groups }\end{array}$ & 2.29 & .70 & 41.5 & 40.7 & 13.7 & 4.1 \\
Citizens & 1.75 & .79 & 20.4 & 30.2 & 43.9 & 5.6 \\
\hline Scientific or academic bodies & 1.71 & .76 & 18.1 & 31.1 & 45.5 & 5.4 \\
\hline
\end{tabular}

One explanation for these findings is that in the world of Swiss associations, direct and responsive relationships to greater public audiences and citizens are of lesser importance than what is professed by democratic theory on social movements and civil society. The primary stakeholders are own members to whom organisations are accountable. This is also reflected in the fact that only $4.6 \%$ of the respondents see this group of addressees as less important and unimportant. The need for democratic legitimacy is embedded in this figure, and it might be helpful to point out that, in most cases, members are not the general public or all citizens but smaller circles of individuals or institutions.

A more detailed analysis that looks at the addressees of interest groups via their policy fields indicates that there are overall similar preferences across policy fields in their communication with external and internal environments (Table 4). Own members are in a primary position, other addressees are perceived to be of medium or high relevance while citizens and scientific or academic bodies are seen as least important for their outward communication. As also other calculations have not delivered clearer indications when interest groups are compared across policy fields, the following data are presented for the whole dataset.

Table 4: Addressees by policy fields of interest groups $(n=961)$

\begin{tabular}{|c|c|c|c|c|c|c|c|c|c|c|c|c|c|c|}
\hline & \multicolumn{2}{|c|}{$\begin{array}{l}\text { Government } \\
\text { and } \\
\text { administration }\end{array}$} & \multicolumn{2}{|c|}{$\begin{array}{l}\text { Parliamentary } \\
\text { factions or } \\
\text { parties }\end{array}$} & \multicolumn{2}{|c|}{ Media } & \multicolumn{2}{|c|}{$\begin{array}{l}\text { Own } \\
\text { members }\end{array}$} & \multicolumn{2}{|c|}{$\begin{array}{l}\text { Other } \\
\text { associations } \\
\text { and interest } \\
\text { groups }\end{array}$} & \multicolumn{2}{|c|}{ Citizens } & \multicolumn{2}{|c|}{$\begin{array}{l}\text { Scientific } \\
\text { or } \\
\text { academic } \\
\text { bodies }\end{array}$} \\
\hline & $\mathrm{n}$ & Mean & $\mathrm{n}$ & Mean & $\mathrm{n}$ & Mean & $\mathrm{n}$ & Mean & $\mathrm{n}$ & Mean & $\mathrm{n}$ & Mean & $\mathrm{n}$ & Mean \\
\hline $\begin{array}{l}\text { Economy and } \\
\text { employment }\end{array}$ & 356 & 3.76 & 356 & 3.14 & 356 & 3.50 & 356 & 4.24 & 356 & 3.38 & 356 & 2.52 & 356 & 2.45 \\
\hline Social life & 52 & 3.42 & 52 & 2.85 & 52 & 3.49 & 52 & 104 & 52 & 3.27 & 52 & & 52 & 2.49 \\
\hline Health & 116 & 3.87 & 116 & 3.24 & 116 & 3.61 & 116 & 4.15 & 116 & 3.48 & 116 & 3.04 & 116 & 2.96 \\
\hline Leisure & 82 & 3.10 & 82 & 2.26 & 82 & 3.44 & 82 & 3.99 & 82 & 2.99 & 82 & 2.54 & 82 & 2.14 \\
\hline Cultu & 47 & .47 & 47 & 2.65 & 47 & 3.43 & 47 & 4.24 & 47 & 3.59 & 47 & 2.72 & 47 & 2.60 \\
\hline Educ & 97 & & 31 & & 97 & 3.09 & 97 & & 97 & 3.40 & 97 & 2.38 & 97 & 2.85 \\
\hline Science & 39 & 34 & 39 & 2.44 & 39 & 2.85 & 39 & 3.95 & 39 & 3.28 & 39 & 2.24 & 39 & 3.82 \\
\hline $\begin{array}{l}\text { Religion/ } \\
\text { Secularism }\end{array}$ & 17 & 3.00 & 17 & 2.73 & 17 & 3.18 & 17 & 3.81 & 17 & 3.06 & 17 & 2.93 & 17 & 2.40 \\
\hline Politics & 101 & 4.14 & 101 & 3.89 & 101 & 3.78 & 101 & 4.20 & 101 & 3.42 & 101 & 3.18 & 101 & 2.73 \\
\hline Environment & 50 & 3.98 & 50 & 3.06 & 50 & 3.74 & 50 & 3.94 & 50 & 3.40 & 50 & 3.06 & 50 & 3.02 \\
\hline Other & 4 & 3.50 & 4 & 3.25 & 4 & 3.50 & 4 & 3.25 & 4 & 3.00 & 4 & 2.50 & 4 & 3.00 \\
\hline
\end{tabular}




\begin{tabular}{lllllllllllllll}
\hline Total & 961 & 3.72 & 961 & 3.03 & 961 & 3.47 & 961 & 4.15 & 961 & 3.36 & 961 & 2.71 & 961 & 2.65 \\
\hline
\end{tabular}

\subsection{Perceived importance of mass media channels}

The respondents were asked for the perceived importance of the various mass media channels, differentiating between print, radio, television and online media (Table 5). Primary importance is ascribed to specialised publications and magazines, both in print and online. The results point out that political associations use their specialised media to exchange relevant information, which is why printed mass media are of overall lesser importance at the local, regional and national levels. Entries in internet social networks (e.g., Facebook, YouTube) and certain blogs or Twitter users are perceived as mostly unimportant.

Overall, $48.2 \%$ of the associations see specialised publications as extremely or very important. Quality newspapers with transregional distribution such as NZZ are of greater importance for $37.8 \%$ of the associations, and $29.4 \%$ attribute stronger importance to regional and local daily newspapers. Sunday papers are seen as rather important by $23.7 \%$, while $48.6 \%$ mark them as less important and unimportant. Low importance is ascribed to political magazines and weeklies (e.g., Weltwoche) where the large majority $(58.6 \%)$ perceives them as less important and unimportant. The overall high relevance of specialised publications can partially be linked to a bias of some associations that includes their own publications. They implicitly mark their own publishing activities and capacities by highlighting these media in order to bring them to researchers' attention.

Also with regard to electronic media, specialised media are considered more important. Both radio and TV are of limited importance, with private radio and local TV being seen as less significant than public service media. Radio SRG and TV SRG are evaluated by $31 \%$ of the associations as extremely important and very important. $20.9 \%$ of the associations consider online news portals (e.g., nzz.ch, tagi.ch) to be of higher relevance, while specialised online media are seen by $29.3 \%$ as extremely and very important, with only $34.3 \%$ considering them as less important and unimportant. It is a strong indicator that these types of internet portals and websites have become relevant in daily work routines, both as news platforms and knowledge archives. 
Social networking sites (SNS) are of comparably little relevance. Only $11.6 \%$ of the associations esteem them as having higher importance while at the same time $66.9 \%$ perceive them as less important and unimportant. Even smaller numbers are found for blogs and twitter that are deemed as less important and unimportant by $77.1 \%$ of the Swiss interest groups.

Table 5: Importance of different media (print and electronic) $(n=985$, in \%)

Question: "Considering the various print media with which you are regularly in contact, how important are these print media for communication by your organisation?" (5-point scale)

\begin{tabular}{lllll}
\hline Print media & $\begin{array}{l}\text { Extremely or } \\
\text { very important }\end{array}$ & Important & $\begin{array}{l}\text { Less } \\
\text { important or } \\
\text { unimportant }\end{array}$ & No answer \\
\hline Quality (transregional) newspapers & 37.8 & 28.4 & 29.3 & 4.5 \\
Regional and local dailies & 29.4 & 27.2 & 38.5 & 4.9 \\
Sunday papers & 23.7 & 20.8 & 48.6 & 6.9 \\
Political magazines and weeklies & 12.2 & 23.0 & 58.6 & 6.2 \\
Specialised publications and magazines & 48.2 & 30.6 & 17.9 & 3.4 \\
\hline
\end{tabular}

Question: "Considering the recipients of your communication and the role of electronic media, how important are these forms of electronic media in sending out communications from your organisation?" (5-point scale)

\begin{tabular}{lllll}
\hline Electronic media & $\begin{array}{l}\text { Extremely or } \\
\text { very important }\end{array}$ & Important & $\begin{array}{l}\text { Less } \\
\text { important or } \\
\text { unimportant }\end{array}$ & No answer \\
\hline Radio - SRG & 31.0 & 26.9 & 36.9 & 5.3 \\
Radio - private & 18.8 & 28.4 & 46.7 & 6.1 \\
TV - SRG & 31.5 & 24.9 & 37.0 & 6.7 \\
TV - local & 16.3 & 23.6 & 53.2 & 6.9 \\
Online news portals (e.g., tagi.ch) & 20.9 & 25.9 & 46.4 & 6.8 \\
Specialised online media & 29.3 & 30.6 & 34.3 & 5.8 \\
Entries in internet social networks (e.g., & 11.6 & 15.6 & 66.9 & 5.9 \\
Facebook, YouTube) & 4.1 & & & 8.0 \\
Certain blogs or Twitter users & & 10.9 & 77.1 & 8 \\
\hline
\end{tabular}

\subsection{Communication instruments for external environments}

Respondents were asked about the instruments of communication that they use in their everyday political life to communicate with their external environments (Table 6). First place is taken by operating and maintaining a website, an instrument used by $90.7 \%$ of all groups. A website is the primary communication tool through which an organisation can directly reach large audiences. They require only a relatively small investment of resources, and one 
can have full control over how the organisation wants to present itself. Instruments from the classical communication mix follow at some distance. $79.7 \%$ of the groups issue informative material (brochures, flyers, publications, etc.), and direct contact with political decisionmakers (e.g., personal or telephone contact) is relevant for $75.6 \%$. Sending out press releases is a frequent activity for $72.6 \%$, and almost two-thirds (63.6\%) of all groups approach journalists either personally or by telephone. The relevance of mass media institutions is thus clearly indicated for a large share of interest groups. 59\% of all groups hold events for special target groups (e.g., for scientists, entrepreneurs and young people). This is a more specifically targeted communication than the more general information transfer by the holding of public events (e.g., panel discussions), an instrument used by $45.4 \%$. In both instances, these types of real-world events are more time-consuming and more costly than the other instruments that can be put to use from office desks.

Sending out an email newsletter seems fairly convenient. The instrument is used by $58.1 \%$ of the associations for outbound communication (and presumably also for internal communication). More demanding instruments such as organising press conferences are not routinely used communication instruments and are done by $37.8 \%$ of the associations. Commissioning or conducting scientific studies is done by $37.7 \%$. Not all associations have the organisational resources to do press conferences or studies, and these activity types tend to be done by the larger umbrella organisations. $26.2 \%$ hold events with direct contact with citizens (e.g., campaigning in public places) and an equal number produce and publish advertising material. If these instruments are considered as public relations management standards, it becomes clear that these types of strategic external communication are only relevant for a minority of political interest groups.

Internet social network activity (e.g., Facebook, YouTube) is an innovative technological possibility and receives much attention from communication studies scholars. They are used for external communication by $21.8 \%$ of the associations. Few organisations $(9.7 \%)$ organise public demonstrations and protests. This low number should not to be mistaken for low importance, but can better be explained by the fact that these activities are extremely demanding on staff. Street march occasions are rare for most associations that work on specific issues. Operating and maintaining a blog or a Twitter account are hardly used (7.3\%), but are perceived to have become more important.

Overall, the majority of communication instruments are those in which organisations have control over content and format, especially concerning an organisation's internet presence and 
its general information material. In this comparative overview on their communication repertoire, the high relevance of interpersonal communication with policy-makers and journalists also becomes visible - personal relationships remain important elements for political interest representation. Concerning the implementation of social networking sites as communication instruments, the proliferation of Facebook and other profiles can be assumed, especially since these new technologies have been rated as increasingly important.

Differentiated analyses of these communication instruments in relation to the actors' policy fields, their regional origin (e.g., German-speaking or French-speaking Switzerland), their primary political activity level (international, national, cantonal or local) and even their organisational size do not provide distinct clues for underlying structural patterns.

Table 6: Instruments used for external communication $(n=985)$

Question: "We are interested in the instruments of communication used by associations and interest groups in everyday political life. First, we will deal with external communications. Which of the following instruments and measures does your organisation use for its external communication?" (Check box if Yes.)

\begin{tabular}{ll}
\hline Communication instrument & $\%$ \\
\hline Operating and maintaining a website & 90.7 \\
\hline Issuing informative material & 79.7 \\
Contact with political decision-makers & 75.6 \\
\hline Press releases & 72.6 \\
\hline Directly approaching journalists & 63.6 \\
\hline Events for special target groups & 59.0 \\
Email newsletter & 58.1 \\
\hline Public events (e.g., panel discussions) & 45.4 \\
Press conferences & 37.8 \\
Commissioning or conducting studies & 37.7 \\
Events with direct contact with citizens & 26.2 \\
Advertising material & 26.2 \\
\hline Activities in internet social networks & 21.8 \\
\hline Public demonstrations and protests & 9.7 \\
\hline A blog or a Twitter account & 7.3 \\
\hline
\end{tabular}

\subsection{Communication instruments for internal environments}

An overview of the instruments used most often for communicating with internal organisational environments, covering both individual and institutional members, is presented 
in Table 7. Regular events (e.g., members' meetings or an annual general meeting) that are held at least annually are carried out by $87.8 \%$ of all associations. Depending on their legal status, this is usually a necessary requirement. Ranked second are direct contacts with members, a routine form of communication done by $78 \%$, followed by $74 \%$ of groups that hold special events for their members (e.g., topical events or information evenings). Established text-based communication channels are email newsletters $(67.6 \%$ of all associations), a mailing list (64.3\%) and a printed members' magazine (62.5\%). All these instruments refer to intra-organisational publishing activities that produce communication. $41.9 \%$ of all groups operate and maintain a (password-protected) members' area on their website. New technologies are used by a minority; $13.2 \%$ use internet social networks to exchange news and views with members (e.g., own groups or Facebook fan pages, own YouTube channel), and 5.4\% operate and maintain a blog or a Twitter account for exchanging news and views with members.

Table 7: Instruments used for internal communication $(n=985)$

Question: "We are interested in the instruments and measures used by associations and interest groups to communicate with their members. Which of the following instruments and measures does your organisation use for its communications with members?" (Check box if Yes.)

\begin{tabular}{ll}
\hline Communication instrument & $\%$ \\
\hline Regular events for members & 87.8 \\
Direct contact with members & 78.0 \\
Special events for members & 74.0 \\
Email newsletter & 67.6 \\
Administration of a mailing list & 64.3 \\
Issuing members' magazine & 62.5 \\
$\begin{array}{l}\text { Operation and maintenance of a (password-protected) } \\
\text { members' area on the website }\end{array}$ & 41.9 \\
$\begin{array}{l}\text { Use of internet social networks to exchange news and views } \\
\text { with members }\end{array}$ & 13.2 \\
$\begin{array}{l}\text { Operation and maintenance of a blog or a Twitter account to } \\
\text { exchange news and views with members }\end{array}$ & 5.4 \\
\hline
\end{tabular}

The usage intensity is highest for website, SNS and blogs/Twitter, a fact that is clearly owed to the technology itself. For those instruments used by many groups, responses for direct communication with members showed that $10 \%$ indicated that they do this on a daily basis, $14 \%$ at least weekly and $25 \%$ at least monthly. Mailing lists are also frequently used. 
Concerning changes in the perception of importance, online media are perceived as increasingly important, despite their low proliferation. A loss of importance was attributed only to members' magazines: $12 \%$ indicated that they have become somewhat less important, $5 \%$ that they have clearly become less important, while 57\% indicated that is was still as important as before. The general trend of a print product decline can thus also be seen in the world of intra-organisational publishing. The large majority of communication is produced within organisations, except for members' magazines (28\%), and events (30\%), which are partially outsourced to external service providers and done in cooperation with partners outside the organisation.

Communication with members, with the exception of annual meetings that are mandatory owing to legal regulations, is still mainly based on face-to-face interactions. Although the majority of organisations use a broad repertoire of instruments to address members, interpersonal communication is not replaced by media technologies. Trust, accountability and support are built as it has always been done: in taking members seriously and establishing personal links. While print products are part of the standard repertoire of almost two-thirds of the participant associations, a fairly large group has also started to include participatory elements in their website. Social media enthusiasts may be disappointed to see relatively few interest groups engaging in these new technologies.

\section{Conclusion}

Communication of interest groups is largely structured and explainable with reference to the logic of influence in contact with policy-makers, and the logic of support in contact with members. Both orientations could be identified in our data. Important addressees are government and administration, parliamentary factions and political parties, in short: actors in the political field. These findings are expectable and are reproduced in a variety of studies that discuss the influence and strategies of interest groups (Binderkrantz \& Krøyer 2012; Dür \& Mateo 2013). However, our study highlights that in the overall picture, the logic of support is of greater importance. Political interest groups are primarily concerned with maintaining responsive links to their members. Our results reconfirm research on interest groups conducted by communication scholars in other countries (Schwarz \& Pforr 2011; Preusse \& Zielmann 2010; Voss 2010; Zeese 2010). 
The perceived relevance of the media also became visible. While campaigning can be read as separate from lobbying (Kollman 1998), and as such falls under the logic of influence, the importance of contact with journalists and frequent observance of various media are also indicators for the logic of reputation. Interest groups not only go public so as to influence, they also go public to run image campaigns and build their reputation as intermediary representatives. However, even in Switzerland, where options for referenda and initiatives could lead us to assume an increase in the likelihood of interest groups addressing the general public, they are not too keen to reach national audiences. The most important and most widely used communication instrument has become the website, as a window and portal to represent themselves as an organisation. Newer forms of online communication are already being used by a few organisations to directly reach supporters.

We assume that the fourth logic - that of reciprocity - needs consideration, since it has so far been fairly invisible. With the focus on interest groups' communication strategies and repertoires, the intertwinements with other interest groups in the intermediary system are relevant. How else could the prominence and relevance of issue-specific media - both in print and online - which address only sectoral audiences be explained? Many groups report that they continuously monitor their immediate surroundings, either because they need to cooperate with other organisations on policy issues, or because they could get into conflict about resources (members, access, publicity, etc.). The results indicate that communicative spaces with other associations are important environments. The existence of fairly densely woven networks between interest groups that work on similar issues can be assumed. Especially in nonpoliticised communication concerned with issue-specific or technical information, frequent correspondence across an organisation's boundaries are part of daily routines. The responses by interest group representatives indicate that these organisations are mainly active in issue-specific audiences. This interpretation is further supported by the stronger relevance of sectoral media. The fourth logic - that of reciprocity - could help bind interest groups to other organisations in their vicinity. Intermediaries connect and link to other actors to become part of information flows and remain up to date on policy developments. These are often informal and therefore almost invisible connections to other group representatives. Communication between intermediaries is also sustained via institutional links and affiliations between associations, sometimes in joint membership in sectoral umbrella organisations or territorially organised chambers of commerce. At a very basic level, these connections show in these organisations reading and publishing in the same issue- 
specific print and online media. It is here where issue-specific audiences manifest as communities of interest.

This interpretation finds further support in the more general observations that most intermediary associations not only have members, but are members of other intermediary organisations too. They are bound into a larger intermediary network, which is extremely well institutionalised in Switzerland. Groups are not isolated monadic organisations, but are connected to each other and sustained by personal interdependencies. It is a frequent phenomenon that representatives sit in several advisory councils, boards of trustees, or working groups of other political associations. Such historically grown networks of binding interrelationships both enable and constrain groups in communicating with their internal and external environments.

The communication of political interest groups in Switzerland has shown to be diverse. The most surprising finding is the high relevance of sectoral media and issue-specific audiences. This opens communication studies to further research on these smaller media worlds' structures and dynamics. 


\section{References}

Armingeon, K. (2007). Die politische Rolle der Verbände in modernen Demokratien. Fünf Thesen. In O. Jarren, D. Lachenmeier, \& A. Steiner (Eds.), Entgrenzte Demokratie? Herausforderungen für die politische Interessenvermittlung (pp. 107-122). Baden-Baden: Nomos.

Baeriswyl, O. (Ed.) (2005). Lobbying in der Schweiz. Partikulärinteressen unter der Bundeskuppel. Villars-Sur-Glâne: Mediata.

Berkhout, J. (2010). Political activities of interest organisations: conflicting interests, converging strategies. Leiden: Leiden University

Beyers, J., Eising, R. \& Maloney, W. (2008). Researching Interest Group Politics in Europe and Elsewhere: Much We Study, Little We Know? West European Politics (Special Issue: The Politics of Organised Interests in Europe: Lessons from EU Studies and Comparative Politics), 31 (6), 1103-1128.

Binderkrantz, A.S. \& Krøyer, S. (2012). Customizing Strategy: Policy Goals and Interest Group Strategies. Interest Groups \& Advocacy 1(1), 115-138

Church, C.H. (2004). Politics and Government of Switzerland. Basingstoke: Palgrave.

Donges, P. (2008). Medialisierung politischer Organisationen. Parteien in der Mediengesellschaft. Wiesbaden: VS Verlag.

Dür, A. \& Mateo, G. (2013). Gaining Access or Going Public? Interest Group Strategies in Five European Countries. European Journal of Political Research, Forthcoming. Available at http://dx.doi.org/10.2139/ssrn.2125812

Eising, R. (2009). The Political Economy of State-Business Relations in Europe: Interest Mediation, Capitalism and European Union Policy Making. London: Routledge.

Habermas, J. (2006). Political Communication in Media Society: Does Democracy Still Enjoy an Epistemic Dimension? The Impact of Normative Theory on Empirical Research. Communication Theory, 16(4), 411-426.

Hackenbroch, R. (1998). Verbändekommunikation. In O. Jarren, U. Sarcinelli, \& U. Saxer (Eds.), Politische Kommunikation in der demokratischen Gesellschaft. Ein Handbuch (pp. 482-488). Opladen: VS Verlag.

Halpin, D. (2010). Groups, representation and democracy. Between promise and practice. Manchester: Manchester University Press. 
Halpin, D. \& Jordan, G. (Eds.) (2012). The Scale of Interest Organization in Democratic Politics: Data and Research Methods. Basingstoke: Palgrave Macmillan.

Hoffjann, O. \& Stahl, R. (Eds.) (2010). Handbuch Verbandskommunikation. Wiesbaden: VS Verlag.

Hoffmann, J., Steiner, A. \& Vogel, M. (2007). Moderne Public Affairs versus traditionelle Interessenvertretung? Agenturen, Unternehmen und Verbände der politischen Kommunikation. Österreichische Zeitschrift für Politikwissenschaft 36(4), 425-444.

Jarren, O., Lachenmeier, D., \& Steiner, A. (Eds.) (2007). Entgrenzte Demokratie? Herausforderungen für die politische Interessenvermittlung. Baden-Baden: Nomos.

Jordan, G. \& Maloney, W. (2007). Democracy and Interest Groups: Enhancing Participation? Basingstoke: Palgrave Macmillan.

Katzenstein, P. (1984). Corporatism and change: Austria, Switzerland, and the politics of industry. Ithaca: Cornell University Press.

Koch-Baumgarten, S. (together with Linke, D.)(2010). Verbände zwischen Öffentlichkeit, Medien und Politik. In O. Hoffjann, \& R. Stahl (Eds.), Handbuch Verbandskommunikation (pp. 239-258). Wiesbaden: VS Verlag.

Kollman, K. (1998). Outside Lobbying. Public Opinion and Interest Group Strategies. Princeton: Princeton University Press.

Kriesi, H. \& Trechsel, A. (2008). The Politics of Switzerland: Continuity and Change in a Consensus Democracy. Cambridge: Cambridge University Press.

Linder, W. (2005). Schweizerische Demokratie: Institutionen - Prozesse - Perspektiven. Bern: Haupt Verlag.

Mach, A. (2007). Interest Groups. In U. Kloeti, P. Knoepfel, H. Kriesi, W. Lindner, \& Y. Papadopoulos (Eds.), Handbook of Swiss politics (pp. 359-380). Zurich: NZZ.

Preusse, J., \& Zielmann, S. (2010). Verbands-PR und Lobbying im Vergleich. In O. Hoffjann, \& R. Stahl (Eds.), Handbuch Verbandskommunikation (pp. 333-352), Wiesbaden: VS Verlag.

Roose, J. (2009). Unterstützungslogik und Informationslogik. Zu zwei Formen der Interessenvertretung im Umweltbereich. In B. Rehder, T. von Winter, \& U. Willems 
(Eds.), Interessenvermittlung in Politikfeldern. Vergleichende Befunde der Policy- und Verbändeforschung (pp. 109-131). Wiesbaden: VS Verlag.

Rucht, D. (2007). Das intermediäre System politischer Interessenvermittlung. In O. Jarren, D. Lachenmeier, \& A. Steiner (Eds.), Entgrenzte Demokratie? Herausforderungen für die politische Interessenvermittlung (pp. 19-32). Baden-Baden: Nomos.

Schroeder, W. \& Weßels, B. (2010). Handbuch Arbeitgeber- und Wirtschaftsverbände in Deutschland: Ein Handbuch. Wiesbaden: VS Verlag.

Schwarz, A., \& Pforr, F. (2011). The crisis communication preparedness of nonprofit organizations: The case of German interest groups. Public Relations Review, 37, 68-70.

Sidjanski, D. (1974). Interest Groups in Switzerland. The Annals of the American Academy of Political and Social Science, 413, 101-123.

Steiner, A. \& Jarren, O. (2009). Intermediäre Organisationen unter Medieneinfluss? Zum Wandel der politischen Kommunikation von Parteien, Verbänden und Bewegungen. In F. Marcinkowski, \& B. Pfetsch (Eds.), Politik in der Mediendemokratie (PVS Sonderheft, 42) (pp. 251-269). Wiesbaden: VS Verlag.

Streeck, W. (1994). Staat und Verbände. Politische Vierteljahresschrift (PVS Sonderheft, 25). Opladen: VS Verlag.

von Winter, T. \& Willems, U. (Eds.) (2007). Interessenverbände in Deutschland. Wiesbaden: VS Verlag.

Voss, K. (2010). Online-Kommunikation von Verbänden. In O. Hoffjann, \& R. Stahl (Eds.), Handbuch Verbandskommunikation (pp. 293-316). Wiesbaden: VS Verlag.

Vowe, G. (2007). Das Spannungsfeld von Verbänden und Medien: Mehr als öffentlicher Druck und politischer Einfluss. In T. von Winter, \& U. Willems (Eds.), Interessenverbände in Deutschland (pp. 465-488). Wiesbaden: VS Verlag.

Wenzler, M. (2009). Journalisten und Eliten. Das Entstehen journalistischer Nachrichten über Energie- und Kulturpolitik. Konstanz: UVK.

Wonka, A., Baumgartner, F., Mahoney, C., \& Berkhout, J. (2010). Measuring the Size and Scope of the EU Interest Group Population. European Union Politics, 11(3), 463-476. Zeese, J. (2010). Verbandszeitschriften: empirische Befunde. In O. Hoffjann, \& R. Stahl (Eds.), Handbuch Verbandskommunikation (pp. 223-236). Wiesbaden: VS Verlag. 
Zeigler, H. (1993). Switzerland: Democratic Corporatism in a Consociational Society. In C. Thomas (Ed.), First World Interest Groups: A Comparative Perspective (pp. 153-164). Westport: Greenwood Press. 